\title{
Development of geomorphic response runoff model for June month for small watersheds
}

Sandip P. Nikam

Correspondence to :

Sandip P. Nikam

Department of Agricultural

Engineering, College of Agriculture (MPKV), Dhule

(M.S.) India

Email : spnikma74@

gmail.com
-ABSTRACT : Computation of runoff due to effective rainfall is essential to estimate soil erosion and sediment load in streams. Moreover, the estimation of runoff distribution with time and peak runoff rate are needed in several hydrologic applications, including design of hydraulic structures, flood prevention works and design of drainage systems. Computation of runoff due to effective rainfall is essential. This requires comprehensive knowledge of the various hydrological phenomena occurring in the catchment. All the watersheds cannot be gauged, as it would be costly and time consuming. Therefore, the indirect method of runoff quantification has to be resorted. The geomorphic parameters are quite useful as they reflect all the causative factors of the runoff. In the present study ten watersheds from Tapi catchment, Maharashtra, India were selected for development of geomorphic response models for prediction of June monthly runoff. Twelve geomorphic parameters were selected for development of model out of which two parameters, $S_{\text {a }}$ and $\mathrm{R}_{\mathrm{b}}$ are screened out in the principal component analysis. Remaining ten parameters are grouped into three physically significant components. The data sets was used to regress the runoff factor, $R / \sqrt{A}$, on three independent parameters (one each from already established components and rainfall factor, $P / \sqrt{A}$. It is observed that percentage deviation ranges from 0.3 to 7.0 using monthly runoff model for June. Therefore, developed runoff can be conveniently used for prediction of June month runoff from unguaged watersheds of the basin having similar physiographic conditions.

- KEY WORDS : Geomorphic response model, Geomorphological parameters, Runoff, Sediment production rate, $\mathrm{PCA}$

- HOW TO CITE THIS PAPER : Nikam, Sandip P. (2019). Development of geomorphic response runoff model for June month for small watersheds. Internat. J. Agric. Engg., 12(1) : 43-47, DOI: 10.15740/HAS/IJAE/12.1/43-47. Copyright@ 2019: Hind Agri-Horticultural Society. 